\title{
Satisfaction of nutritionists who work in food service
}

\section{Satisfação dos nutricionistas que atuam na alimentação coletiva}

\author{
Rayane Luizi da COSTA ${ }^{1}$ (D) 0000-0002-7427-1570 \\ Lize STANGARLIN-FIORI2 (ID) 0000-0001-7904-904X \\ Renata Labronici BERTIN1 (iD) 0000-0002-3876-655X \\ Caroline Opolski MEDEIROS1 (iD) 0000-0001-7299-9149
}

A B S T R A C T

\section{Objective}

To evaluate the job satisfaction of nutritionists who work in food service in the state of Paraná (Brazil).

\section{Methods}

A survey was carried out with 249 nutritionists through a semi-structured online questionnaire, which assessed their profile, professional activities, and job satisfaction. The Mann-Whitney and Kruskal-Wallis tests and the ordinal logistic regression at a 5\% significance level were applied to evaluate the differences and relationship between job satisfaction and the independent variables.

\section{Results}

The average age of the survey participants was $31.9 \pm 6.4$ years, the majority was female $(95.58 \%)$, and graduated between 2000 and 2016 (90.36\%). The survey revealed that $55.41 \%$ of the nutritionists were satisfied at work, 33.68\% were indifferent, $6.86 \%$ were highly satisfied, and $4.04 \%$ were dissatisfied. The variables that influenced job satisfaction the most were age, years of training, income, and workdays in the week. Income explained satisfaction positively. There was statistical difference in relation to the satisfaction of participants regarding their knowledge on food service $(p=0.0350)$, completion of postgraduate courses $(p=0.0082)$, and interest in working in an area of nutrition other than food service $(p<0.0001)$.

\footnotetext{
${ }^{1}$ Universidade Federal do Paraná, Setor de Ciências da Saúde, Departamento de Nutrição. Av. Pref. Lothário Meissner, 632, Jd. Botânico, 80210-170, Curitiba, PR, Brasil. Correspondence to: CO MEDEIROS. E-mail: <caroline.opolski@gmail.com>.

2 Universidade Federal do Paraná, Setor de Ciências da Saúde, Programa de Pós-Graduação em Alimentação e Nutrição. Curitiba, PR, Brasil.
}

\footnotetext{
How to cite this article

Costa RL, Stangarlin-Fiori L, Bertin RL, Medeiros CO. Satisfaction of nutritionists who work in food service. Rev Nutr. 2019;32:e180168. http://dx.doi.org/10.1590/1678-9865201932e180168
} 


\section{Conclusion}

Although most professionals are satisfied, many were indifferent to job satisfaction, which may reflect a low perspective on their current job or poor experience in the food service. These results suggest the need for further actions aiming at raising nutritionists' perceived professional importance.

Keywords: Food service. Job satisfaction. Nutritionists.

\section{RESU M O}

\section{Objetivo}

Avaliar a satisfação no trabalho dos nutricionistas que atuam na área de alimentação coletiva no estado do Paraná.

\section{Métodos}

Pesquisa realizada com 249 nutricionistas, por meio de um questionário semiestruturado online, que avaliou o perfil, o exercício profissional e a satisfação do nutricionista. O teste Mann-Whitney, Kruskal-Wallis e a regressão logística ordinal com nível de significância de 5\% foram utilizados para avaliar a diferença e relação entre a satisfação e as variáveis.

\section{Resultados}

A idade média dos respondentes foi de $31,9 \pm 6,4$ anos, sendo a maioria do sexo feminino $(95,58 \%)$ e graduado entre 2000 e 2016 (90,36\%). Constatou-se que 55,41\% dos nutricionistas estavam satisfeitos no trabalho, $33,68 \%$ indiferentes, 6,86\% altamente satisfeitos e 4,04\% insatisfeitos. As variáveis que mais influenciaram a satisfação foram a idade, os anos de formação, o salário e os dias da semana de trabalho, sendo que a renda explicou positivamente a satisfação. Houve diferença estatística com relação à satisfação dos participantes com a avaliação do conhecimento sobre alimentação coletiva $(p=0,0350)$, a realização de pós-graduação $(p=0,0082)$ e o interesse em atuar em outra área da nutrição que não a alimentação coletiva $(p<0,0001)$.

\section{Conclusão}

Apesar de a maioria dos profissionais estarem satisfeitos, muitos foram indiferentes à satisfação no trabalho, podendo refletir ausência de perspectiva sobre seu trabalho atual ou indicar a falta de familiaridade com a alimentação coletiva. Os dados indicam a necessidade de mais ações de valorização junto a esses profissionais.

Palavras-chave: Serviços de alimentação. Satisfação no trabalho. Nutricionistas.

\section{INTRODUCTION}

In several countries, the population's food consumption pattern has been changing over the years [1], including a significant increase in out-of-home eating during the last few decades [2,3]. In Brazil, this growth is also evident, as $40.2 \%$ of food consumption has been done outside home [4]. As a result, there has been an increase in the number of food service companies [5] and, consequently, of job opportunities for nutritionists.

The most important responsibility of nutritionists who work in food service is to manage the food establishment in order to provide quality and nutritionally adequate food to the population [6-8]. In this challenging segment, the role of the nutritionist as a technical manager has become essential, leading them to take on professional and legal commitments in the execution of mandatory and complementary activities in Food Service Systems [8,9].

Despite the high professional demand in the food service industry, some nutritionists are not satisfied and motivated to practice their profession in this area, and are migrating to other segments after some time of experience $[10,11]$. These facts may be related, above all, to the accumulation of routine activities; to the predominance of administrative activities; to conflicts of interest between 
the company and the nutritionist; to excessive working hours and low pay; and to poor technical knowledge about what constitutes adequate food and health promotion $[10,11]$.

The nutritionists' dissatisfaction in their work may adversely affect productivity, services, employees, and customers of the company, in addition to favoring the hire of unqualified people [12]. Therefore, understanding the variables related to the satisfaction of these professionals in food service is important to promote a balance between job offer and demand [13].

Fifty years after the regulation of the nutritionist profession in Brazil - guaranteed by the enactment of Law No.5276/1967 and later by Law No.8234/1991 [14,15] - and development of several career opportunities in food service, there has been little evidence on the job satisfaction of these professionals in this area in the last years, both in Brazil [11] and in other countries [12,16-18].

In Brazil, there is still little research on job satisfaction amongst nutritionists working with food service. Clear understanding of the factors that influence nutritionists' job satisfaction may lead to greater professional valorization. Considering that job satisfaction surveys are of fundamental importance to the area of organizational behavior, this study aims at evaluating the satisfaction of nutritionists who work in the food service industry in the state of Paraná (Brazil).

\section{METHO D S}

This research is a cross-sectional design that follows an exploratory and quantitative approach, which was conducted with nutritionists who work with food service in the state of Paraná. Ethical aspects were respected and the research was approved by the Research Ethics Committee of the Universidade Federal do Paraná (UFPR, Federal University of Paraná), document No.1.670.435.

\section{Sample}

The sample included professionals who worked in one or more areas of food service during the research period: restaurants, school feeding programs, and/or Worker's Food Programs [6]. The sample size was determined considering the total number of nutritionists enrolled in the $8^{\text {th }}$ Regional Councils of Nutrition (RCN-8) $(n=6,791)$ in the first half of 2016. Considering that the RCN-8 was not able to provide specific data on the number of nutritionists who worked with food service, the percentage used was based on a study by Vasconcelos \& Calado [19], which identified that 32.3\% of nutritionists were working in this area.

Nutritionists who worked in the public health area in that period (8.8\%) [19] were also included in the sample because some professionals might work in the Workers' Food Program or the National School Feeding Program, but were not classified within the food service area. The Workers' Food Program and the National School Feeding Program are national programs designed by the Brazilian Federal Government to promote better nutrition for workers and schoolchildren.

Therefore, the number of nutritionists working in food service in the state of Paraná during the research period was estimated as $41.1 \%(n=2,805)$. Based on this value, a prevalence of $50.0 \%$ with a $5.0 \%$ margin of error and $95.0 \%$ confidence level were used. The study sample resulted in 338 nutritionists. The sample size was calculated using the open access program OpenEpi online, version $3.01[20]$. 
The inclusion criteria for participating in the research were: being a nutritionist; working in the food service industry in Paraná during the research period; being registered in the RCN-8; being at least 18 years-old; and having fully answered the questionnaire.

\section{Research instrument}

For data collection, a semi-structured survey questionnaire was developed online in the software Survey Monkey based on literature review. The questionnaire was divided into three blocks: (1) Identification of the participant [12,16,21,22]; (2) Professional activity $[6,12,16,21,22]$; and (3) Job satisfaction level $[12,16,23,24]$. The participants were enquired about their sociodemographic and professional profile, including gender, age, characteristics of training, weekly workload, workdays in the week, shifts, number of work sites, work location, income, among others.

Job satisfaction was evaluated through a list of 19 items, which was elaborated by the authors. Each item was assessed using the five-points Likert scale, where 1 represents 'Extremely dissatisfied' and 5, 'Extremely satisfied' $[23,25]$.

Face validity was conducted with seven nutritionists with experience in food service in order to assess the satisfaction scale [25]. Following evaluation, a pre-test was carried out with seven nutritionists to assess the ease of access to the questionnaires, the participants' understanding of the information and questions presented, and the time required to complete the survey. Then, some changes were performed in order to render the questions clearer.

\section{Data collection}

The data was collected between October 2016 and January 2017. Nutritionists were informed of the survey by an e-mail sent by the RCN-8 to those who were registered in the council and additionally by e-mails circulated in city halls in the State of Paraná, catering companies, restaurants, bakeries, event suppliers, nutrition consultants, hospitals, colleges and universities, and elementary and middle school administration offices. The professionals were also invited to disseminate the research. Prior to accessing the online questionnaire, the participants were referred to the Free and Informed Consent Form.

The time to complete the questionnaire was approximately 25 minutes. It was not possible to estimate the exact average response time as the participants were able to pause and restart the online questionnaire at any time. Additionally, the participants could give up on the research after signing the consent form.

\section{Statistical Analysis}

Only fully completed questionnaires were considered in the data analysis. The data was analyzed in the statistics software Statistical Package for the Social Sciences version 21.0 (SPSS, Chicago, Illinois, United States) [26] by descriptive statistical analysis. Job satisfaction was evaluated according to satisfaction scores, as recommended by Lopes [27].

Satisfaction scores were determined through the standardization of the scores obtained from the Likert scale. The resulting standardized scale ranged from 0 to 100. Individuals who obtained a score from 0 to 39.9 were classified as dissatisfied; a score from 40.0 to 59.9 was classified as 
indifferent; a score from 60.0 to 79.9 was classified as satisfied; and a score of 80.0 to 100 classified the individual as highly satisfied. In order to evaluate the relationship between job satisfaction and independent variables, an ordinal logistic regression analysis was performed. The variables were selected through Stepwise.

Mann-Whitney and Kruskal-Wallis tests were used to compare job satisfaction with sociodemographic and professional factors. In addition, the reliability of the satisfaction scale was evaluated in terms of internal consistency using the Cronbach's alpha coefficient. The level of significance set in all analyzes was 95\% ( $p<0.05)$.

\section{RES ULTS}

In total, 358 individuals accessed the online survey, but only 249 (69.5\%) nutritionists completed the questionnaire. Most respondents were female (95.58\%), with an average age of $31.9 \pm 6.4$ years, who graduated college between 2000 and $2016(90.36 \%)$ in private institutions (70.68\%). Most of them completed a postgraduate course $(75.90 \%)$, and their first employment started up to six months after graduation (71.08\%) (Table 1). Although $43.78 \%$ of the nutritionists evaluated the knowledge on food service acquired during their undergraduate course as good, $26.51 \%$ considered such knowledge regular.

Most nutritionists (38.96\%) had a 31 to 40 hour-working week, and $27.31 \%$ worked more than 40 hours per week. Furthermore, $73.49 \%$ of them worked five days per week; $89.96 \%$ worked in morning and afternoon shifts; $77.11 \%$ worked as nutritionists in food service in only one location; and $67.74 \%$ were paid between two and five minimum wages (Table 1).

In addition, $65.86 \%$ of the nutritionists considered that there was a need for specific training in food service. More than half of the nutritionists (59.04\%) reported an interest in another area of nutrition (Table 1). The main reasons to change area were: affinity with another area $(42.86 \%)$; future objectives/new experiences (14.29\%); and low current wage (10.88\%). Finally, the areas of greatest interest were: Clinical (46.9\%); Teaching (37.4\%); and Public Health (32.0\%) (Table 2).

Amongst the attributes evaluated, there was statistical difference in relation to job satisfaction according to age $(p=0.0389)$, year of graduation $(p=0.0379)$, knowledge on food service $(p=0.0350)$, conclusion of postgraduate courses $(p=0.0082)$, interest in acting in an area of nutrition other than food service $(p<0.0001)$, and income in the food service industry $(p=0.0193)$ (Table 1).

Table 3 shows the distribution of nutritionists in the state of Paraná during the research period according to the job satisfaction level and attributes assessed. The results were: (a) $6.86 \%$ of the nutritionists were highly satisfied; (b) $55.41 \%$ were satisfied; (c) $33.68 \%$ were indifferent; and (d) $4.04 \%$ were dissatisfied. There was statistical difference between the mean percentage of satisfied and dissatisfied individuals $(p<0.001)$.

The items that corresponded to a higher satisfaction level (highly satisfied and satisfied) were: ergonomic conditions (62.75\%), communication with subordinates $(62.50 \%)$, time limit for decision-making $(62.50 \%)$, conduction of administrative functions $(62.50 \%)$, noise at work $(62.50 \%)$, and temperature and humidity in the work environment $(62.50 \%)$.

The ordinal logistic regression was performed initially with the variables age, training time, salary, time to obtain the first job as a nutritionist, number of work sites, time spent in the food service industry, workdays in the week, and weekly workload. The final model showed that only 
Table 1. Distribution of nutritionists who work in the state of Paraná according to sociodemographic characteristics and job satisfaction. Curitiba (PR), Brazil, 2017

1 of 2

\begin{tabular}{|c|c|c|c|c|c|c|}
\hline \multirow{3}{*}{ Variables } & \multicolumn{2}{|c|}{ Participants } & \multicolumn{4}{|c|}{ Job Satisfaction } \\
\hline & \multirow{2}{*}{$n$} & \multirow{2}{*}{$\%$} & \multicolumn{3}{|c|}{ Mean score** } & \multirow{2}{*}{$p$-value } \\
\hline & & & M & & SD & \\
\hline Gender $^{1}$ & & & & & & 0.1651 \\
\hline Female & 238 & 95.58 & 63.55 & \pm & 12.75 & \\
\hline Male & 11 & 4.42 & 59.57 & \pm & 14.21 & \\
\hline $\mathrm{Age}^{2}$ & & & & & & $0.0389^{*}$ \\
\hline Up to 29 years & 100 & 40.16 & 64.86 & \pm & $11.98^{\mathrm{a}}$ & \\
\hline 30 to 39 years & 115 & 46.18 & 60.95 & \pm & $12,93^{\mathbf{b}}$ & \\
\hline 40 to 49 years & 29 & 11.65 & 66.87 & \pm & $13.81^{\mathrm{a}}$ & \\
\hline More than 50 years & 5 & 2.01 & 69.15 & \pm & $13.18^{a}$ & \\
\hline Year of graduation ${ }^{2}$ & & & & & & $0.0379^{*}$ \\
\hline Up to 1989 & 5 & 2.01 & 69.36 & \pm & $22.66^{\mathrm{a}}$ & \\
\hline 1990 to 1999 & 19 & 7.63 & 70.16 & \pm & $11.05^{\mathrm{a}}$ & \\
\hline 2000 to 2009 & 133 & 53.41 & 62.82 & \pm & $12.64^{\mathbf{b}}$ & \\
\hline 2010 to 2016 & 92 & 36.95 & 62.46 & \pm & $12.49^{b}$ & \\
\hline Type of University/College where the undergraduation in Nutrition was completed ${ }^{1}$ & & & & & & 0.4942 \\
\hline Public & 73 & 29.32 & 62.92 & \pm & 12.79 & \\
\hline Private & 176 & 70.68 & 64.48 & \pm & 12.87 & \\
\hline Knowledge on food service acquired during undergraduation ${ }^{2}$ & & & & & & $0.0350^{*}$ \\
\hline Bad & 14 & 5.62 & 59.58 & \pm & $15.76^{\mathbf{b}}$ & \\
\hline Regular & 66 & 26.51 & 60.27 & \pm & $10.37^{\mathbf{b}}$ & \\
\hline Good & 109 & 43.78 & 64.01 & \pm & $13.67^{\mathrm{a}}$ & \\
\hline Very good & 47 & 18.88 & 66.09 & \pm & $12.22^{\mathrm{a}}$ & \\
\hline Excellent & 13 & 5.22 & 68.08 & \pm & $12.60^{\mathrm{a}}$ & \\
\hline Need for specific training in order to work in food service ${ }^{1}$ & & & & & & 0.3261 \\
\hline Yes & 164 & 65.86 & 62.90 & \pm & 12.91 & \\
\hline No & 85 & 34.14 & 64.29 & \pm & 12.64 & \\
\hline Completion of postgraduate course ${ }^{1}$ & & & & & & $0.0082^{*}$ \\
\hline Yes & 189 & 75.90 & 64.70 & \pm & $12.40^{\mathrm{a}}$ & \\
\hline No & 60 & 24.10 & 59.22 & \pm & $13.36^{\mathbf{b}}$ & \\
\hline Interest in working in an area of nutrition other than food service ${ }^{1}$ & & & & & & $<0.0001^{*}$ \\
\hline Yes & 147 & 59.04 & 60.42 & \pm & $13.06^{\mathbf{b}}$ & \\
\hline No & 102 & 40.96 & 67.64 & \pm & $11.20^{\mathrm{a}}$ & \\
\hline Weekly working hours in food service ${ }^{2}$ & & & & & & 0.3817 \\
\hline$<10$ hours & 10 & 4.02 & 58.19 & \pm & 16.43 & \\
\hline 10 to 15 hours & 6 & 2.41 & 67.20 & \pm & 11.66 & \\
\hline 16 to 20 hours & 46 & 18.47 & 64.01 & \pm & 12.77 & \\
\hline 21 to 30 hours & 22 & 8.84 & 68.23 & \pm & 9.78 & \\
\hline 31 to 40 hours & 97 & 38.96 & 63.13 & \pm & 12.14 & \\
\hline$>40$ hours & 68 & 27.31 & 62.16 & \pm & 13.98 & \\
\hline
\end{tabular}


Table 1. Distribution of nutritionists who work in the state of Paraná according to sociodemographic characteristics and job satisfaction. Curitiba (PR), Brazil, 2017.

\begin{tabular}{|c|c|c|c|c|c|c|}
\hline \multirow{3}{*}{ Variables } & \multicolumn{2}{|c|}{ Participants } & \multicolumn{4}{|c|}{ Job Satisfaction } \\
\hline & \multirow{2}{*}{$\mathrm{n}$} & \multirow{2}{*}{$\%$} & \multicolumn{3}{|c|}{ Mean score ${ }^{* *}$} & \multirow{2}{*}{$p$-value } \\
\hline & & & M & & SD & \\
\hline Workdays in the week in food service ${ }^{2}$ & & & & & & 0.4603 \\
\hline 1 & 2 & 0.80 & 58.51 & \pm & 9.02 & \\
\hline 2 & 12 & 4.82 & 66.22 & \pm & 5.67 & \\
\hline 3 & 23 & 9.24 & 65.22 & \pm & 13.42 & \\
\hline 4 & 14 & 5.62 & 66.64 & \pm & 8.26 & \\
\hline 5 & 183 & 73.49 & 62.82 & \pm & 13.55 & \\
\hline 6 & 13 & 5.22 & 64.65 & \pm & 9.57 & \\
\hline 7 & 2 & 0.80 & 50.00 & \pm & 10.54 & \\
\hline Work shift in food service ${ }^{2}$ & & & & & & 0.3064 \\
\hline Morning & 16 & 6.43 & 61.44 & \pm & 11.91 & \\
\hline Afternoon & 3 & 1.20 & 70.92 & \pm & 5.25 & \\
\hline Evening & 2 & 0.80 & 53.72 & \pm & 11.28 & \\
\hline Morning and afternoon & 224 & 89.96 & 63.32 & \pm & 12.92 & \\
\hline Afternoon and evening & 1 & 0.40 & 71.28 & \pm & 00.00 & \\
\hline Morning, afternoon, and evening & 3 & 1.20 & 74.47 & \pm & 12.94 & \\
\hline Number of jobs in food service ${ }^{2}$ & & & & & & 0.8843 \\
\hline 1 & 192 & 77.11 & 63.66 & \pm & 13.07 & \\
\hline 2 & 34 & 13.65 & 62.02 & \pm & 12.30 & \\
\hline 3 & 9 & 3.61 & 63.12 & \pm & 13.31 & \\
\hline 4 & 14 & 5.62 & 62.92 & \pm & 11.07 & \\
\hline First job as nutritionist (time in months after completing undergraduation) $)^{2}$ & & & & & & 0.5740 \\
\hline Up to 6 months & 177 & 71.08 & 64.09 & \pm & 13.10 & \\
\hline 7 to 11 months & 14 & 5.62 & 62.39 & \pm & 12.42 & \\
\hline 12 to 23 months & 32 & 12.85 & 61.07 & \pm & 10.34 & \\
\hline 24 to 35 months & 14 & 5.62 & 63.07 & \pm & 14.85 & \\
\hline More than 36 months & 12 & 4.82 & 60.55 & \pm & 13.26 & \\
\hline Income in food service ${ }^{2}$ & & & & & & $0.0193^{*}$ \\
\hline Up to 1 minimum wage & 6 & 2.42 & 59.04 & \pm & $8.20^{\mathrm{a}}$ & \\
\hline More than 1 to 2 minimum wages & 49 & 19.76 & 59.75 & \pm & $12.25^{\mathrm{a}}$ & \\
\hline More than 2 to 3 minimum wages & 84 & 33.87 & 61.56 & \pm & $13.33^{\mathrm{a}}$ & \\
\hline More than 3 to 5 minimum wages & 84 & 33.87 & 66.65 & \pm & $11.23^{\mathbf{b}}$ & \\
\hline More than 5 to 10 minimum wages & 21 & 8.47 & 66.72 & \pm & $13.38^{\mathbf{b}}$ & \\
\hline More than 10 to 20 minimum wages & 4 & 1.61 & 67.82 & \pm & $26.24^{\mathrm{b}}$ & \\
\hline
\end{tabular}

Note: ${ }^{1}$ Mann-Whitney Test; ${ }^{2}$ Kruskal-Wallis Test (Dunn test: same letters do not differ statistically, $\left.{ }^{*} p>0.05\right) .{ }^{* *}$ Minimum value is 0 and maximum value is 100 . Score from 0 to 39.9 was classified as dissatisfied; 40.0 to 59.9 was classified as indifferent; 60.0 to 79.9 was classified as satisfied; and 80.0 to 100 was classified as highly satisfied.

Minimum wage $=R \$ 880.00$. 
Table 2. Information on the interest of nutritionists who work in food service in changing to a different area. Curitiba (PR), Brazil, 2017.

\begin{tabular}{|c|c|c|c|c|}
\hline \multirow[t]{2}{*}{ Characteristics of the shift to a different area } & \multicolumn{2}{|c|}{$\begin{array}{l}\text { People who wanted to } \\
\text { change area }(n=147)\end{array}$} & \multicolumn{2}{|c|}{$\begin{array}{c}\text { People who did not want to } \\
\text { change area }(n=102)\end{array}$} \\
\hline & $\mathrm{n}$ & $\%$ & $n$ & $\%$ \\
\hline \multicolumn{5}{|c|}{ Reasons for being interested in changing to a different area ${ }^{a}$} \\
\hline Affinity with another area & 63 & 42.86 & 27 & 26.47 \\
\hline Future goals/new experiences & 21 & 14.29 & & \\
\hline Low current wage & 16 & 10.88 & & \\
\hline Work simultaneously in another area & 14 & 9.52 & & \\
\hline Not satisfied in the current area & 13 & 8.84 & & \\
\hline Low level of perceived importance & 11 & 7.48 & & \\
\hline Experience in the area/Technical improvement & & & 2 & 1.96 \\
\hline Blic service stability & & & 1 & 0.98 \\
\hline No answer & 22 & 14.97 & 73 & 71.57 \\
\hline \multicolumn{5}{|l|}{ Areas of interest $t^{\mathbf{b}}(n=147)$} \\
\hline Clinical & 69 & 46.90 & & \\
\hline Teaching & 55 & 37.40 & & \\
\hline Public Health & 47 & 32.00 & & \\
\hline Food Industry & 21 & 14.30 & & \\
\hline Sports Nutrition & 34 & 23.10 & & \\
\hline Marketing in food and nutrition & 24 & 16.30 & & \\
\hline Other ${ }^{c}$ & 5 & 3.40 & & \\
\hline
\end{tabular}

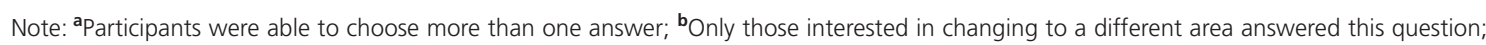
'Other areas the participants would like to work in: entrepreneurship $(n=2)$; supply chain $(n=1)$; sanitary control $(n=3)$; nutrition focused on gastronomy $(n=2)$; aesthetic nutrition $(n=1)$; nutritional education $(n=1)$.

Table 3. Scale of job satisfaction presented to nutritionists who work in food service in the state of Paraná, Brazil - internal reliability of the scale and distribution of nutritionists. Curitiba (PR), Brazil, 2017.

\begin{tabular}{|c|c|c|c|c|c|c|c|c|}
\hline \multirow{2}{*}{ Scale of satisfaction } & \multicolumn{2}{|c|}{ Highly satisfied } & \multicolumn{2}{|c|}{ Satisfied } & \multicolumn{2}{|c|}{ Indifferent } & \multicolumn{2}{|c|}{ Dissatisfied } \\
\hline & n & (\%) & $n$ & $(\%)$ & $\mathrm{n}$ & $(\%)$ & $\mathrm{n}$ & $(\%)$ \\
\hline Professional motivation & 17 & 7.00 & 133 & 54.73 & 83 & 34.16 & 10 & 4.12 \\
\hline Perceived professional importance & 17 & 6.83 & 138 & 55.42 & 84 & 33.73 & 10 & 4.02 \\
\hline Income & 17 & 6.85 & 137 & 55.24 & 84 & 33.87 & 10 & 4.03 \\
\hline Job stability & 17 & 6.88 & 137 & 55.47 & 83 & 33.60 & 10 & 4.05 \\
\hline Opportunities for growth in the company & 17 & 6.85 & 137 & 55.24 & 84 & 33.87 & 10 & 4.03 \\
\hline Relationship with superiors & 17 & 6.83 & 138 & 55.42 & 84 & 33.73 & 10 & 4.02 \\
\hline Relationship with subordinates & 17 & 6.83 & 138 & 55.42 & 84 & 33.73 & 10 & 4.02 \\
\hline Communication with superiors & 17 & 6.88 & 136 & 55.06 & 84 & 34.01 & 10 & 4.05 \\
\hline Communication with subordinates & 17 & 6.85 & 138 & 55.65 & 83 & 33.47 & 10 & 4.03 \\
\hline Time limit for decision-making & 17 & 6.85 & 138 & 55.65 & 83 & 33.47 & 10 & 4.03 \\
\hline Menu planning budget & 17 & 6.83 & 138 & 55.42 & 84 & 33.73 & 10 & 4.02 \\
\hline Conduct administrative functions & 17 & 6.85 & 138 & 55.65 & 83 & 33.47 & 10 & 4.03 \\
\hline Division of tasks & 17 & 6.83 & 138 & 55.42 & 84 & 33.73 & 10 & 4.02 \\
\hline Working hours & 17 & 6.83 & 138 & 55.42 & 84 & 33.73 & 10 & 4.02 \\
\hline Workload & 17 & 6.88 & 136 & 55.06 & 84 & 34.01 & 10 & 4.05 \\
\hline Noise in the work environment & 17 & 6.85 & 138 & 55.65 & 83 & 33.47 & 10 & 4.03 \\
\hline Ergonomic conditions & 17 & 6.88 & 138 & 55.87 & 82 & 33.20 & 10 & 4.05 \\
\hline Temperature and humidity in the work environment & 17 & 6.85 & 138 & 55.65 & 83 & 33.47 & 10 & 4.03 \\
\hline Physical structure of the work site & 17 & 6.83 & 138 & 55.42 & 84 & 33.47 & 10 & 4.02 \\
\hline Level of overall satisfaction & & 6.86 & & 55.41 & & 33.68 & & 4.04 \\
\hline Cronbach's alpha & & & & & & & & \\
\hline
\end{tabular}


age, training time, income, and workdays in the week influenced job satisfaction (C195\%) (Table 4). However, income was the only variable that explained satisfaction positively, while age, years of training, and days worked in the week explained the results negatively.

Table 4. Ordinal logistic regression of variables associated with job satisfaction levels of nutritionists who work in food service in the state of Paraná. Curitiba (PR), Brazil, 2017

\begin{tabular}{|c|c|c|c|c|}
\hline \multirow{3}{*}{ Variables } & \multicolumn{4}{|c|}{ Satisfaction level } \\
\hline & \multicolumn{4}{|c|}{ Regression } \\
\hline & $\beta_{\text {adjusted }}^{\mathbf{a}} \mathbf{b}$ & $p$-value & & \\
\hline Age & -0.091 & 0.020 & -0.167 & -0.015 \\
\hline Yearc & -0.109 & 0.013 & -0.195 & -0.023 \\
\hline Income & 0.436 & 0.002 & 0.157 & 0.715 \\
\hline Days $^{\mathbf{d}}$ & -0.304 & 0.032 & -0.580 & -0.027 \\
\hline
\end{tabular}

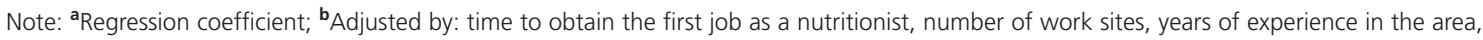
and weekly workload; ' Years of graduation/training; dWorkdays in the week.

\section{DISCUSSION}

The results of this study enabled the assessment of the job satisfaction of nutritionists who work in food service in the State of Paraná, Southern Brazil. The online research made it possible to approach a greater number of professionals, even though a portion of them gave up on the survey after having accepted the invitation. However, it is difficult to state the reason for the withdrawal. According to Buchanan \& Williams [28], the dropout in online surveys may be higher compared to face-to-face research because the participant simply closes the browser window to finish the process. The reasons for quitting may be diverse, but researchers have not yet agreed on how to reduce the dropout rates $[28,29]$. In any case, the results obtained in this research are of great relevance, even considering the dropout.

Nutritionists were satisfied with working in food service, including with exerting administrative functions. Sauer et al. [12] evaluated the job satisfaction of nutritionists registered in the American Dietetic Association (ADA) $(n=1,200)$ using a questionnaire comprising 36 items. They found higher satisfaction levels among professionals who had greater administrative responsibilities, especially in the area of budget management. Nevertheless, nutritionists were mostly dissatisfied in other studies [11] - perhaps because they performed activities outside of their scope [30]. Additionally, professional motivation remains being the most dissatisfactory attribute among nutritionists in food service.

Although most professionals claimed to be satisfied at work, a high percentage of nutritionists was indifferent to the items in the scale (33.68\%). This result is similar to the ones observed in others studies [11,12]. Sauer et al. [12] verified that $31.8 \%$ of the professionals were neither satisfied nor dissatisfied, whereas Souza et al. [11] reported that $22.0 \%$ of the 129 nutritionists graduated in a Northeast Brazilian university were indifferent to job satisfaction and satisfaction with their professional knowledge. 
Using a central (neutral) category on the scale can make respondents feel more comfortable when answering a survey. However, the neutral category can generate ambivalence and indifference, shading the respondents' true opinion [31]. In addition, job satisfaction is related to feeling joy during work. This outcome becomes a serious concern since there is no concrete opinion on the subject. Additionally, this may reflect a lack of perspective on the nutritionist's current work, as well as poor overall wellbeing and life satisfaction levels. Conclusions on life satisfaction are reported by GraceFarfaglia et al. [18], who evaluated personal life satisfaction levels amongst nutritionists in the US. Work-life balance showed to be the main factor influencing life satisfaction.

Another relevant factor to the job satisfaction of nutritionists was their interest in changing work area. Most participants were interested in changing area, especially the ones who reported low job satisfaction levels. This result is in accordance with another research, which showed that dissatisfied workers either contribute more significantly to labor turnover [32] or have higher intention to change jobs [12].

Individuals older than 40 years and those who graduated in the 90's showed higher job satisfaction levels. A similar result was found by Visser et al. [16] and Chin et al. [24], who reported that age and time of experience independently have a positive influence on job satisfaction. However, time of experience did not impact on life satisfaction among nutritionists [18].

However, younger professionals may evaluate as positive some aspects that middle-aged workers believe to be causes of dissatisfaction. This is a common scenario, as younger workers usually desire to learn and acquire new experiences. On the other hand, older professionals adapt better to new employments and have more objective views, as they usually have greater professional experience. Thus, older professionals may assign higher values to aspects that others consider dissatisfactory [33].

Proper training has also influence on job satisfaction. Nutritionists who were more satisfied at work were those who classified their knowledge in food service as excellent. For instance, Almeida et al. [34] conducted a systematic review and observed the importance of the relationship between theory and practice, the dimensions of teaching, research and extension, and practical activities and internships for the development of skills and competencies of nutritionists who work in the public health area.

Even though this study focuses on nutritionists who work with food service, their relationship with public health is important, since these professionals have to comply with public policies that are currently included in the activities of Food Service Systems (e.g.: Workers' Food Program; National School Feeding Program) [8].

These results reinforce the commitment that undergraduate courses of nutrition should have in the construction of pedagogical political projects. Such projects should be elaborated collectively and centered on the student as subject, while lecturers should be facilitators of the teaching-learning process, respecting both the Curriculum Guidelines of the National Nutrition Undergraduate Course [35] and the nutritionist's area of activity. Not only the nutritionists' attributions [7] influence their job satisfaction, but also the knowledge acquired during undergraduate and postgraduate courses.

Moreover, Grace-Farfaglia et al. [17] found that life satisfaction of US nutritionists were influenced directly and positively by a greater orientation towards wellness and a healthy lifestyle. 
Thus, undergraduate courses should comprise modules on wellness and health self-management, which contribute to life satisfaction.

In addition, continued training should also be emphasized, since the professionals who completed postgraduate courses were more satisfied with their profession - similar results were found by Abad-Jorge \& Butcher [36]. This fact shows that knowledge and constant update can provide better opportunities for professional advancement and value. It is noteworthy that only the knowledge obtained from undergraduate training may be insufficient to manage public health issues that keep increasing in complexity.

Moreover, job satisfaction was affected by income, which explained the results positively. A study by Chin et al. [24] with nutritionists in South Korea presented similar results. Other studies have also shown that low pay is the major cause of professional dissatisfaction $[7,11,16]$. Sauer et al. [12] also stress that the relationship between job satisfaction and income can often be related not only to the salary itself, but also to the position occupied by the professional.

Most nutritionists that participated in this research had a monthly income between $R \$ 1,760.00$ and $R \$ 4,440.00$, but not all of them worked 40 hours/week. Currently, the National Reference for a nutritionist's wage value (44 hours/week) is $\mathrm{R} \$ 2,389.36$ per month [37], which corresponds to 2.5 minimum wages [38].

The results found in this research indicate the need for higher perceived professional importance through the action of labor unions in various Brazilian states, since the National Reference for nutritionists' wage does not follow the annual adjustment of the minimum wage. It is worth highlighting the absence of a labor union operating in the state of Paraná.

This study presents some limitations. The sample was non-probabilistic, thus the data may not represent the reality of all nutritionists in the state of Paraná. In addition, even though this research had been widely publicized, some professionals may have not managed to access it or have not received the invitation. Naturally, not all professionals who were invited to the survey accepted to participate. Even though the satisfaction scale presented excellent internal consistency and a face validity step was performed, further researches are needed to validate this satisfaction scale and assess its reproducibility. Despite some limitations, this research adds important data to the literature on job satisfaction levels of nutritionists who work with food service as it identifies aspects that might increase nutritionists' perceived professional importance.

\section{CONCLUSION}

Most nutritionists who participated in this research were satisfied with their work in the food service industry, and their income was strongly associated with job satisfaction. However, the considerable percentage of professionals who were indifferent to job satisfaction suggested that either some participants might not be aware of the issues mentioned, or they perform their activities without focusing on job satisfaction. They may also not be enough familiarized with the food service segment.

Further studies are required to understand the reasons why professionals who work with food service are willing to migrate to a different area. This may aid the development of effective actions aimed at improving professional valorization by councils, trade unions, and the professionals themselves. 


\section{CONTRIBUTORS}

RL COSTA and CO MEDEIROS contribution to data acquisition and drafting the article. CO MEDEIROS, L STANGARLIN-FIORI and RL BERTIN contribution to conception and design and critically revising it for important intellectual content. The authors contributed to data analysis and interpretation and final approval of the article.

\section{ACKNOWLEDGMENTS}

The $8^{\text {th }}$ Regional Councils of Nutrition for the support in our research. The Academic Publishing Advisory Center (CAPA - www.capa.ufpr.br) of the Universidade Federal do Paraná for assistance with English language editing.

\section{REFERENCES}

1. Popkin BM. Nutrition transition and the global diabetes epidemic. Curr Diab Rep. 2015;5(9):64. http://dx.doi. org/10.1007/s11892-015-0631-4

2. Lund TB, Kjærnesb U, Holma L. Eating out in four Nordic countries: National patterns and social stratification. Appetite. 2017;119(1):23-33. http://dx.doi.org/10.1016/j.appet.2017.06.017

3. D'Addezio L, Turrini A, Capacci S, Saba A. Out-of-home eating frequency, causal attribution of obesity and support to healthy eating policies from a cross-European survey. Epidemiol Biostat Public Health. 2014;11(4):e9921-1-13. http://dx.doi.org/10.2427/9921

4. Instituto Brasileiro de Geografia e Estatística. Pesquisa de orçamentos familiares 2008-2009: análise do consumo alimentar pessoal no Brasil. Rio de Janeiro: IBGE; 2011.

5. Associação Brasileira das Indústrias de Alimentação. Mercado. 2016 [citado 2018 dez 9]. Disponível em: https://www.abia.org.br/vsn/tmp_2.aspx?id=319

6. Conselho Regional de Nutricionistas. Resolução CFN n³80/2005. Dispõe sobre a definição das áreas de atuação do nutricionista e suas atribuições, estabelece parâmetros numéricos de referência por área de atuação e dá outras providências. Brasília: Diário Oficial da União; 2006.

7. European Federation of the Associations of Dietitians. Position paper on the role of the food service dietitian. 2016 [cited 2018 Dec 9]. Available from: http://vladio.be/wp-content/uploads/2017/06/Postition-paper-onthe-role-of-the-food-service-dietitian.pdf

8. Conselho Regional de Nutricionistas. Resolução CFN n600/2018. Dispõe sobre a definição das áreas de atuação do nutricionista e suas atribuições, indica parâmetros numéricos mínimos de referência, por área de atuação, para a efetividade dos serviços prestados à sociedade e dá outras providências. Brasília: Diário Oficial da União; 2018.

9. Academy Quality Management Committee. Academy of Nutrition and Dietetics: Revised 2017 scope of practice for the registered dietitian nutritionist. J Acad Nutr Diet. 2018;118(1):141-65. http://dx.doi. org/10.1016/j.jand.2017.10.002

10. Souza AA, Bezerra OMPA, Bonomo E, Silva CAM. Atuação de nutricionistas responsáveis técnicos pela alimentação escolar de municípios de Minas Gerais e Espírito Santo. Ciênc Saúde Coletiva. 2017;22(2):593-606. http://dx.doi.org/10.1590/1413-81232017222.12272016

11. Souza JCN, Fagundes A, Silva DG, Barbosa KBF. Education, satisfaction and professional prospects of nutrition graduates of a federal university in the Brazilian northeast. Demetra. 2018;13(1):5-20. http:// dx.doi.org/10.12957/demetra.2018.28602

12. Sauer K, Canter D, Shanklin C. Job satisfaction of dietitians with management responsibilities: An exploratory study supporting ADA's research priorities. J Acad Nutr Diet. 2012;112(5):S6-11. http://dx.doi.org/10.1016/j. jand.2012.03.020

13. Ferraz R, Lopes E. Satisfação no trabalho: comparação de duas escalas de medida por meio de equações estruturais. Rev Port Bras Gestão. 2015 [citado 2018 Dec 9];14(1):37-47. Disponível em: https://www. redalyc.org/pdf/3885/388541155005.pdf 
14. Congresso Nacional (Brasil). Lei $n^{\circ 5.276}$, de 24 de abril de 1967. Dispõe sobre a profissão de Nutricionista, regula o seu exercício, e dá outras providências. Brasília: Diário Oficial da União; 1967.

15. Congresso Nacional (Brasil). Lei n8.234, de 17 de Setembro de 1991. Regulamenta a profissão de Nutricionista e determina outras providências. Brasília: Diário Oficial da União; 1991.

16. Visser J, Mackenzie A, Marais D. Job satisfaction of South African registered dietitians. S Afr J Clin Nutr. 2012 [cited 2018 Dec 9];25(3):112-9. Available from: http://www.sajcn.co.za/index.php/SAJCN/article/view/615

17. Grace-Farfaglia P, Pickett-Bernard D, Gorman AW, Dehpahlavan J. Health philosophy of dietitians and its implications for life satisfaction: An exploratory study. Behav Sci. 2017;7(67):eE67. http://dx.doi.org/10.3390/ bs7040067

18. Grace-Farfaglia PM, Pickett-Bernard DL, Gorman AW, Dehpahlavan J. Keep calm and lead by example: Healthy lifestyles of dietitians and satisfaction with life. J Prev Med. 2018;3(1):1-6. http://dx.doi.org/10.21767/2572-5 483.100027

19. Vasconcelos FAG, Calado CLA. Profissão nutricionista: 70 anos de história no Brasil. Rev Nutr. 2011;24(4):605-17. http://dx.doi.org/10.1590/S1415-52732011000400009

20. Dean AG, Sullivan KM, Soe MM. OpenEpi: Open source epidemiologic statistics for public health. [cited 2018 Dec 9]. Available from: https://www.openepi.com/SampleSize/SSPropor.htm

21. Conselho Federal de Nutricionistas. Perfil da atuação profissional do nutricionista no Brasil. Brasília: CFN; 2006.

22. Mello AL, Vidal Júnior PO, Sampaio LR, Santos LAS, Freitas MCS, Fontes GAV. Perfil do nutricionista do programa nacional de alimentação escolar na região Nordeste do Brasil. Rev Nutr. 2012;25(1):119-32. http:// dx.doi.org/10.1590/S1415-52732012000100011

23. Saane N, Sluiter JK, Verbeek JHAM, Frings-Dresen MHW. Reliability and validity of instruments measuring job satisfaction: A systematic review. Occup Med. 2003;53(3):191-200. http://dx.doi.org/10.1093/occmed/ kqg038

24. Chin JH, You JS, Chang KJ. Comparison of role conflict, self-efficacy, job satisfaction, and job involvement between nutrition teachers and dietitians at School Food Service in Incheon Metropolitan City-Focusing on the interactions between nutrition teachers and dietitians. Korean J Nutr. 2012;5(1):64-79. http://dx.doi. org/10.4163/kjn.2012.45.1.64

25. Di lorio CK. Measurement in health behavior: Methods for research and education. San Francisco: Josset Bass; 2005.

26. International Business Machines Corporation. IBM SPSS Statistics for Windows, Version 21.0. Armonk: IBM Corp; 2012.

27. Lopes LFD. Métodos quantitativos. Santa Maria: Universidade Federal de Santa Maria; 2016.

28. Buchanan T, Williams JE. Ethical issues in psychological research on the Internet. In: Gosling SD, Johnson, JA. Advanced methods for conducting online behavioral research. Washington (DC): American Psychological Association; 2010.

29. Allen PJ, Roberts LD. The impact of academic sponsorship on Web survey dropout and item non response. First Monday. 2016;21(2). http://dx.doi.org/10.5210/fm.v21i2.6144

30. Pires PFF, Retondario A, Almeida CCB, Schmidt ST, Beux MR, Ferreira SMR. Professional practice of dietitians in the Brazilian School Feeding Program: A multiple case study. Rev Nutr. 2017;30(4):499-510. http://dx.doi. org/10.1590/1678-98652017000400009

31. Willts FK, Theodori GL, Luloff AE. Another look at Likert Scales. J Rural Soc Sci. 2016 [cited 2018 Dec 9];31(3):126-39. Available from: http://journalofruralsocialsciences.org/pages/Articles/JRSS\%202016\%2031/3/JRSS\%202016 \%2031\%203\%20126-139.pdf

32. Machado DC, Silva AF. Um indicador de não satisfação no trabalho e a mobilidade do mercado de trabalho: um estudo para homens e mulheres. Nova Econ. 2014;24(1):123-40. http://dx.doi.org/10.1590/0103-6 $351 / 1410$

33. Carrillo-García C, Solano-Ruíz MC, Martínez-Roche ME, Gómez-García Cl. Influência do gênero e da idade: satisfação no trabalho de profissionais da saúde. Rev Latino-Am Enferm. 2013;21(6):1314-20. http://dx.doi. org/10.1590/0104-1169.3224.2369 
34. Almeida GM, Oliveira KHD, Monteiro JS, Medeiros MAT, Recine EGIG. Educational training of nutritionists in Public Health Nutrition: A systematic review. Rev Nutr. 2018;31(1):97-117. http://dx.doi.org/10.1590/1678-9 8652018000100009

35. Conselho Nacional de Educação. Câmara de Educação Superior. Resolução CNE/CES N5, de 7 de novembro de 2001. Institui Diretrizes Curriculares Nacionais do Curso de Graduação em Nutrição. Diário Oficial da União, Seção 1, p.19, 2001.

36. Abad-Jorge A, Butcher MF. Job satisfaction and professional characteristics of registered dietitians a survey of the impact of educational level during entry level practice. Top Clin Nutr. 2016;31(2):134-46. http://dx.doi. org/10.1097/TIN.0000000000000064

37. Federação Nacional dos Nutricionistas. Tabela de honorários nutricionistas. 2017 [citado 2018 dez 9]. Disponível em: https://www.fnn.org.br/conteudos/arquivos/tabela_2017.pdf

38. Presidência da República (Brasil). Decreto 8.948, de 29 de dezembro de 2016. Regulamenta a Lei $n^{\circ} 13.152$, de 29 de julho de 2015, que dispõe sobre o valor do salário mínimo e a sua política de valorização de longo prazo. Diário Oficial da União, Seção 1, p.12, 2016. 